УАК 342

ББК 67.400

DOI 10.22394/1682-2358-2017-6-31-36

Sh.A. Kholikova, degree seeking applicant of the Academy of Public Administration under the President of the Republic of Uzbekistan

\section{PROSPECTS \\ FOR IMPROVING \\ PUBLIC CONTROL \\ IN THE CONTEXT \\ OF CIVIL SOCIETY \\ FORMATION \\ IN UZBEKISTAN}

Issues of improving public control at the modern stage of development of Uzbekistan are researched. The necessity of unification of the legislation in this sphere is emphasized, as well as the adoption of a single system-forming and basic law.

Key words and word-combinations: public control, civil society, state government bodies, Uzbekistan.
Ш.А. Холикова, соискатель Академии государственного управления при Президенте Республики Узбекистан (email: abdugafarovna@ mail.ru)

\section{ПЕРСПЕКТИВЫ СОВЕРШЕНСТВОВАНИЯ ОБЩЕСТВЕННОГО КОНТРОАЯ В УСАОВИЯХ ФОРМИРОВАНИЯ ГРАЖААНСКОГО ОБЩЕСТВА В УЗБЕКИСТАНЕ}

Аннотаичия.Исследуются вопросы совершенствования общественного контроля на современном этапе развития Узбекистана. Подчеркивается необходимость унификации законодательства в данной сфере, а также принятие единого системообразующего и базового закона.

Ключевые слова и словосочетания: общественный контроль, гражданское общество, органы государственного управления, Узбекистан.

C тия Республика Узбекистан пережика гранАиозные преобразования, при этом главной цемью было укрепиение независимости и государственного суверенитета. Масштабные изменения в стране базировались на программе структурных реформ, получившей признание в мире как «узбекская модель» развития. Пять принципов, которые мегли в основу Аанной формулы, явицись прочным фундаментом Аальнейшего обеспечения помитических, экономических и соџиальных трансформаџий в Узбекистане. 
На президентских выборах 4 декабря 2016 г. народ Узбекистана прогомосовал за Шавката Мирзиёева. В этот день страна фактически вступила в новый этап своего развития. В 2017 г. быц дан старт масштабным административным реформам и соџиально-экономическим преобразованиям бцагодаря утвержденной Государственной программе, реализуемой в «ГоА Аиалога с народом и интересов человека» и Стратегии действий по пяти приоритетным направлениям развития Республики Узбекистан в 2017-2021 гг. [1] .

Суть реформ выразилась в главном принципе «Не народ Аолжен служить государственным органам, а государственные органы должны служить народу» [2, с. 45]. Аиалог межАу властью и гражданами стал совершенно иным, позволив укоренить в обществе справедливость, сблизить руководителей, чиновников с населением. Впервые был внеАрен институт Виртуальной приемной Президента Республики Узбекистан, а также народные приемные Президента, открытые в районах и городах всех регионов, посредством которых было получено свыше 1,5 млн обрашений граждан [3]. Само число жалоб и преАможений, их содержание свидетельствует об уровне доверия узбекистанџев к главе государства и новому институту.

Следует отметить, что посредством данного механизма на деле решены проблемы сотен тысяч граждан, более того, обрашения стали богатым материалом дмя изучения положения дел в разных сферах. Эта уникальная практика была позитивно отмечена множеством зарубежных специалистов. Сегодня рассматривается вопрос об организации эффективного оказания государственных услуг через народные приемные, которой будет заниматься Служба по защите прав гражжан, контролю и координации работы с обращениями физических и юридических киџ аппарата Президента Республики Узбекистан, а также Агентство оперативных государственных услуг при Министерстве юстиџии Республики Узбекистан.

С первых мет независимости важнейшим направяением демократических реформ стало формирование сильного гражданского общества в Узбекистане, обеспечение конститущионных прав и свобод человека. Многочисленные гражАанские институты становятся мощным фактором защиты демократических ценностей, прав, свобод и законных интересов мюдей. Они создают условия Аля реализации гражданами своего потенџиала, повышения общественной, соџиально-экономической активности и правовой культуры.

ОАнако при отсутствии контроля со стороны общества органы государственной власти не всегда добросовестно и эффективно выполняют свои обязанности. Именно поэтому актуальной задачей в сфере развития действенных гражданских институтов остается создание эффективных механизмов осуществления общественного контроля за деятельностью органов государственной власти и управления. Попытаемся исследовать перспективы совершенствования общественного контроля в условиях формирования гражданского общества в Узбекистане.

Развитие гражАанского общества в Узбекистане рассматривается как важнейшая предпосылка построения правового государства. Вместе с тем формирование гражданского общества - это длительный непрерывный проџесс, 
сопряженный с определенными трудностями. Гражданское общество воз-

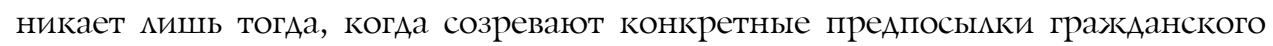
компромисса и мировоззренческого плюрализма, скцадывается совокупность общественных институтов, способных взаимодействовать и вести равноправный диалог с государством и его органами, а в отдельных случаях быть противовесом, сдерживая его стремление к монополии [4] .

Зарубежный опыт свидетельствует о том, что контроль со стороны общества способствует эффективному функционированию государственного аппарата, повышает ответственность государственной власти, компетентность и профессионализм чиновников, обеспечивая надлежащее исполнение законов, а также уважение прав и свобод граждан. В то же время государство, компетентная вмасть при помощи обратной связи с обществом способна брать за основу конструктивные предложкения граждан и проводить в стране необходимые реформы, опираясь на их доверие и поддержку. В Узбекистане, как и в Аругих странах постсоветского пространства, общественный контроль рассматривается в качестве некого образца, на который стоит ориентироваться вмасти и гражданскому обществу.

В странах с развитыми демократиями иные условия взаимодействия государства и гражданских инициатив формируют иную практику реализации общественного контроля, который вкмючает Аостаточно широкий набор инструментов и зиждется на принципах прозрачности государственной власти и партиципации общества. Общественный контроль зарожАался как необходимость учета общественного мнения при решении государственных вопросов. При этом само словосочетание «общественный контроль» на Западе практически не употребляется.

В США, например, институт контроля общества за властью стал скмадываться вместе с появлением и функционированием организаций гражданского общества. Из существующих в США сегодня 1,5 мин [5] общественных организаций особый тип представляют «общественные организации, осуществляющие контроль наА действиями властей... наА проведением выборов и выполнением предвыборных обещаний, проводят расследования и изобличают факты коррупции, а также активно выступают от имени национацьных меньшинств» [6]. В Германии неправительственные организации, наряду с мегитимными учреждениями в миџе пармамента и независимых судов, также явцяются кАючевым сегментом общественного контроля, содействуя подАержанию консенсуса в обществе [7].

Основные формы осуществления общественного контроля в разцичных странах были подробно изучены и рассмотрены в работах российского исслеАователя Е.А. Огневой. Ученый отмечает: «Современные интерпретации сущности общественного контроля раскрывают многогранность этого явления, что отражкается в признании одновременно его самостоятельности и необходимости правой регламентации; необходимости эффективного взаимодействия государства и общества, развития многообразных форм общественного контроця, более активного привлечения гражАан к управлению делами госуАарства и общества» [8] . 
В качестве основных признаков общественного контромя Е.А. Огнева выдемяет следующие:

- обшественный контроль выступает среАством обеспечения баланса интересов различных социальных групп;

- цель общественного контроля состоит в защите прав человека посреАством объединения и согласования усилий гражданского общества;

- общественный контроль явмяется гарантом выполнения соџиальных норм;

- обшественный контроль распространяется на различные сферы госуАарственной деятельности;

- обшественный контроль имеет массовый характер, основан на широком участии разных слоев общества;

- участие в осуществлении общественного контроля носит добровольный характер [8] .

В Узбекистане проводятся поэтапные реформы, направленные на укрепление организаџионно-правовых основ общественного контроля. В Конститущии Республики Узбекистан закреплена ответственность государства переА обществом. Общественному контролю придан конститущионный статус благодаря изменениям и дополнениям, внесенным в Конституцию Республики Узбекистан 16 апремя 2014 г. [9].

На данный момент более чем в сорока нормативно-правовых актах предусматривается право институтов гражданского общества на осуществление общественного контроля в таких сферах, как охрана окружающей среды, образование, зАравоохранение, социальная защита населения, защита прав потребителей, охрана соџиально-экономических прав граждан. Значительный практический опыт наработан органами самоуправления гражАан, профессиональными союзами, Экологическим движением Узбекистана, негосударственными некоммерческими организациями [10] .

Вместе с тем анализ правовых основ общественного контроля в Узбекистане показывает необходимость перехода на качественно новый уровень - от фрагментарной тематики к более обобщающему закону, то есть необходимы унификация законодательства в данной сфере, а также принятие единого системообразующего и базового закона. Кроме того, в действующих нормативно-правовых актах Узбекистана, регулирующих вопросы осуществления общественного контроля, не раскрыты в достаточной мере механизмы его реализации. С целью миквидации этих недостатков в указанной Стратегии действий предусмотрена разработка специального законопроекта «Об общественном контроле», который в настоящее время проходит общественное обсуждение.

В предлагаемом законопроекте под общественным контролем подразумевается «реализация гражданами Республики Узбекистан гарантированного Конституцией Республики Узбекистан права на участие в управлении деками общества и государства, посредством осуществления общественного контроля наА деятельностью государственных органов» [11]. При этом закон направмен на урегулирование отношений, связанных с реализаџией гарантированных

34 Bulletin of the Volga Region Institute of Administration • 2017. Vol. 17. № 6 
Конститущией прав граждан на управление общественными и государственными деками. Закон призван определить субъекты, объекты и предмет обшественного контроля, правовые механизмы его осуществления, права и обязанности граждан и институтов гражданского общества, а также государственных органов в этой сфере.

Законопроект включает 21 статью. В нем опредемяются цель закона, система законодательства об общественном контроле, субъекты, объект общественного контромя, его основные принџипы и формы. Так, субъектами общественного контромя предлагается определить граждан Узбекистана, органы самоуправления граждан, ННО, СМИ. Предусматривается, что общественный контроль может осуществмяться общественными советами, комиссиями и в Аругих организаџионных формах в случаях, предусмотренных законодательством. Объектом общественного контроля определяется деятельность государственных органов и их должностных миџ:

- по учету обшественных интересов, обшественного мнения в принимаемых нормативно-правовых актах, решениях, а также в государственных, отраслевых и региональных программах развития;

- обеспечению исполнения требований законодательства в сфере защиты прав и законных интересов граждан, юридических миџ, интересов общества;

- эффективному выполнению возложенных на них задач и функций, затрагивающих соџиальные и общественные интересы;

- эффективному и качественному оказанию государственных услуг;

- реализации соглашений, договоров, проектов и программ, осушествмяемых в рамках социального партнерства.

Законопроектом предусматриваются такие формы обшественного контро^я, как обращения и запросы в государственные органы; участие на открытых коммегиальных заседаниях государственных органов; общественное обсуждение; общественное слушание; общественный мониторинг; общественная экспертиза; изучение обшественного мнения; заслушивание органами самоуправления гражАан отчетов руководителей органов исполнительной власти и Аругих организаџий.

В законопроекте раскрывается механизм реализации общественного контроля, описана процедура подведения итогов осуществления форм общественного контроля, перечислены права и обязанности субъектов общественного контроля, государственных органов в этой области.

Следует отметить, что проџессы становления системы обшественного контроля и институџионализаџии механизмов участия гражданского общества в обшественном контроле в Узбекистане требуют решения проблемы повышения уровня вовлеченности насемения и институтов гражданского общества в осуществление общественного контроля. В свою очередь, это порождает необходимость принятия дополнительных мер по повышению прозрачности и подотчетности деятельности органов государственного управления, стимулирования иниџиатив институтов гражданского общества, а также повышения доверия к ним со стороны граждан и органов государственной власти.

Институты гражданского общества, находясь в тесной взаимосвязи с госу- 
Аарственными органами, явмяются переходным звеном, отражающим интересы, настроения, отношения к господствующей политической власти и состояние общества в целом. В сложные экономические и политические периоды исторического развития государства гражданский сектор становится мощной силой, подАерживающей государство, а государство содействует формированию гражданского общества. В то же время институты гражданского общества не Аолжны полностью поглотить государство, подменив осуществление его основных функщий негосударственными структурами. Без эффективной реализации государством своих основных функций невозможно создание и развитие полноценного гражданского общества в Узбекистане.

\section{Библиографический список}

1. О Стратегии действий по дальнейшему развитию Республики Узбекистан: Указ Президента Республики Узбекистан от 7 февр. 2017 г. № УП-4947. URL: http://lex.uz/pages/getpage. aspx?lact_id $=3107042$

2. Мирзиеев Ш.М. Мы все построим свободное, демократическое и процветающие государство Узбекистан: выступление на торжественной церемонии вступления на должность Президента Республики Узбекистан на совместном заседании палат Олий Мажлиса. Ташкент, 2016.

3. Доклад Президента Республики Узбекистан Шавката Мирзиеева на торжественном собрании, посвященном 25-й годовщине принятия Конституции Республики Узбекистан. URL: https://www.gov.uz/ru/news/view/13350

4. Бегматов A.C. Становление и развитие политической системы и гражданского общества в Узбекистане // Этапы демократизации политической системы, либерализации и развития гражданского общества: материалы «круглого стола», проведенного 24 февраля 2015 г., Ташкент // Жамият ва бошкарув (Ташкент). 2015. № 1. С. 38-39.

5. URL: https://www.state.gov/j/drl/rls/fs/2017/266904.htm

6. Майкфол М. Гражданское общество Америки // Независимая газета. 2013. 29 апр. URL: http://www.ng.ru/ideas/2013-04-29/1_us_society.html

7. Селиванова E.C. Международный опыт в институционализации общественного контроля в современной России // Вестник ВГУ. Сер.: История. Политология. Социология. 2014. № 2. C. 112-116.

8. Огнева Е.А. Общественный контроль в системе защиты прав и свобод человека и гражданина Российской Федерации: конституционно-правовое исследование: дис. ... канд. юрид. наук. М., 2015. С. 33-62.

9. Конституция Республики Узбекистан. Ташкент, 2017.

10. Маликова Г.Р. Общественный контроль в системе сдержек и противовесов (к постановке вопроса) // Жамият ва бошкарув (Ташкент). 2014. № 1. С. 55-59.

11. Об общественном контроле: проект Закона Республики Узбекистан. URL: http://strategy.uz/files/jamoatchilik.pdf 